\title{
Water mites of the genus Neumania Lebert (Acari, Hydrachnidia: Unionicolidae: Pionatacinae) in the Mediterranean area
}

\author{
V. Pešićit*, R. Gerecke², M. Cîmpean ${ }^{3}$
}

'Department of Biology, Faculty of Sciences, University of Montenegro, 81000 Podgorica, Serbia and Montenegro
${ }^{2}$ Biesingerstr. 11, 72070 Tübingen, Germany
${ }^{3}$ Department of Taxonomy and Ecology, Faculty of Biology and Geology, Babes-Bolyai University, Cluj-Napoca, Romania.

A catalogue of the water mites of the genus Neumania Lebert is given for the countries surrounding the Mediterranean Sea. Morphological details and taxonomical position are discussed. For each species, geographical distribution and habitat preference are given. The following synonyms are established: Neumania algeriensis Bader, $1989=N$. seurati Walter, 1931; N. atlantida Lundblad, $1942=N$. uncinata Walter, 1927. The synonymization of N. agilis Koenike, 1916 with N. limosa (Koch, 1836) is confirmed. Due to incomplete description and lack of type material, N. vietsi Husiatinschi, 1937 should be considered a species incerta. The following first records are given for national faunas: Neumania elliptica (France, Italy); N. phreaticola (Italy, Slovenia); N. uncinata (Greece, Israel, Italy, Bosnia and Herzegovina, Montenegro).

Keywords: Water mites, diversity, taxonomy, Mediterranean, temporary running waters, interstitial.

\section{Introduction}

Pionatacinae Lebert, 1879 , is a subfamily of water mites rich in diversified phyletic lines distributed mostly in tropical and subtropical areas (Cook 1974), but in the European fauna represented only by species of the genus Neumania Lebert, 1879. Most of the known Neumania species are obligate lenitobionts, only a few species are able to colonize streams where they are found in detritusrich pools; one species of the European fauna has adapted to the hyporheic interstitial. The aim of this paper is to present new data that contribute to our knowledge about the morphology, geographical distribution, and habitat preference of Mediterranean members of the genus, mostly resulting from field work of the authors during the past decades.

\section{Materials and methods}

Samples from surface waters were taken by hand netting and sorted on the spot from the living material, interstitial samples taken with Karaman-Chappuis digs

*Corresponding author: E-mail: pesicv@cg.yu were sorted in the laboratory under a stereo microscope. Specimens were preserved in Koenike's fluid and dissected as described elsewhere (e.g. Gerecke et al. 2006). Slide-mounted specimens and material preserved in fluid is curated in the collections of the authors. In the section 'Material examined' collecting site abbreviations derive from the geographical database Gerecke. For each country the current province abbreviations are used, the composition of the material is given as: (males/females/deutonymphs).

The following abbreviations are used: Ac- $1=$ first acetabula; asl = above sea level; $\mathrm{CX}-1$ = first coxae; $\mathrm{H}=$ height; I-L-6 = Leg 1, sixth segment; L = length; MNHN $=$ Musee nationale d'Histoure naturelle Paris; NHMB = Naturhistorisches Museum Basel; P-1 = palp, first segment; SMF = Senckenberg-Museum Frankfurt; $\mathrm{W}=$ width. All measurements are given in $\mu \mathrm{m}$. The term „swimming setae“ is applied for setae which are particularly long and slender. They are mostly found arranged close together at the distal edge of the posterior margin of segments 3-5, furthermore, a little stronger and arranged at larger distance, along the segment on the anterior surface of IV-L-4 and IV-L-5. 


\section{Results}

A record from the northern border of the study area, but excluded from the following list, regards Neumania (Lemienia) simulans (Koenike, 1893). This Ethiopian species widely distributed $\mathrm{S}$ to the Sahara was recorded by Georgevitsch (1903) from Serbia, but never found again since then. Numerous species of the subgenus Lemienia are known from tropical Africa and Asia, all characterized by a sexual dimorphism of the IV/L, with bowed terminal segment in males. As such bowing may be found occasionally also in members of other subgenera due to misshapening, this single record from far outside the distribution area of the taxon is most probably based on a misidentification.

\section{Genus Neumania Lebert, 1879}

\section{Subgenus Neumania Lebert, 1879}

\section{Neumania (s.str.) deltoides (Piersig, 1894)}

Records from the Mediterranean: Bosnia and Herzegovina: Trebinje (Pešić 2003b); France: Cevennes (Angelier et al. 1963), Dauphine ( «N. triangularis» Motaş 1926), Touraine ( «N. triangularis» Motaş 1928); Greece: Corfu (? - Stephanides 1971), Thessalia (K. Viets 1950); Italy: Lazio (Marucci 1902, Nocentini 1973), Lombardia («N. triangularis» Maglio 1903); Piemonte (Nocentini 1963), Umbria (Taticchi 1968, Cicolani \& Di Sabatino 1985); Macedonia: Skoplje, Lake Ohrid (K. Viets 1936a, Georgiev 1957, «N. agilis» Pešić 2003a); Montenegro: Skadar Lake (K. Viets 1936a, «N. agilis» Pešić 2002); Portugal: Cintra, Ferreira (Lundblad 1956); Serbia: Belgrade ( $\ll N$. triangularis» Georgevitsch 1903); Spain: Castellon, Salamanca (Lundblad 1956), Sierra de Guadarrama (Valdecasas \& Camacho 1986).

Material examined: Montenegro: Skadar Lake, Malo Blato, village Bobija, 14.08.2000, Pešić (10/5/1).

Material compared: SMF, Germany: K.Viets, Krefeld, Hinsbecker Bruch, 08.08.1928 46136 \#m, \#f; 46135 juv. \#f. K.O.Viets, Aue Totarm near Westerscheps, 23.08.1946 53216 \#m 53217 \#f, 53218 \#f; Husum 20.07.1954 53232 \#m, 63233 \#f. Cechia, Adelsberg, Schwarze Grotte, Spoecker 46161 (labeled "limosa") 46161 \#m; Spain, Zaragoza, Quinta Julieta, 09.04.1917, 46156 \#f.

Description: (based on material from Skadar Lake, Malo Blato, village Bobija, 14.08.2000, Pešić): Skin with minute chitinous papillae; dorsum with two pairs of small muscle attachment platelets anteriorly; dorsal glandularia very small except for one pair of glandularia tubercles in the posterior part; coxal surface reticulate; genital plates with 14-21 pairs of Ac; excretory pore surrounded by a prominent, tubercle-like sclerite ring, lying at posterior idiosoma margin. Palp morphology and setation: Figs 1 B-C; P-4 with a peg-like seta inserting on a projection near the ventrodistal edge of segment, ventral setae arranged close to each other, denticles near their insertions little developed or completely absent. Legs: swimming setae numbers: III-L-4 3-4; III-L-5 3; IV-L-3 3, IV-L-4 3-5, IV-L-5 3-5.

Male: Idiosoma L/W 607-643/500-478; coxal field $\mathrm{L}$ (distance between anterior end of first, and posterior end of fourth coxae) 438-440; genital field L/W 162194/165-200; with 14-19 pairs of Ac (Fig. 1 D). Palp total $\mathrm{L} 282-284$; dorsal $\mathrm{L}$ and relative $\mathrm{L}$ (\% of total $\mathrm{L}$, in parentheses) of palp segments: P-1 28 (9.9), P-2 8486 (29.6-30.5), P-3 50-51 (17.7-18.3), P-4 86-87 (30.530.6), P-5 32-33 (11.4-11.6); P-2/P-4 ratio 0.97-1.0; legs dorsal L measurements: I-L-1 56-61, I-L-2 106118, I-L-3 153-159, I-L-4 202-215, I-L-5 232-238, I-L6 230-232; IV-L-1 91-95, IV-L-2 121-123, IV-L-3 $183-$ 191, IV-L-4 229-230, IV-L-5 256-259, IV-L-6 230238.

Female: Idiosoma (Fig. 1 A) L/W 730-850/490-700; coxal field L 577-635; genital field close to posterior margin, W 244-338; genital plates L 125-147, W 8097, with 19-21 pairs of Ac. Palp total L 352-371; dorsal $\mathrm{L}$ and relative $\mathrm{L}$ (\% of total $\mathrm{L}$, in parentheses) of palp segments: P-1 32-35 (9.1-9.9), P-2 107-118 (30.331.8), P-3 62-65 (17.5-18.4), P-4 106-115 (30.1-31.0), P-5 38-40 (10.3-11.4); P-2/P-4 ratio 0.98-1.03; legs dorsal L measurements: I-L-1 70-71, I-L-2 141, I-L-3 183-200, I-L-4 277-282, I-L-5 288, I-L-6 235; IV-L-1 91-129, IV-L-2 147-159, IV-L-3 223-234, IV-L-4 271279, IV-L-5 306-312, IV-L-6 277-282.

Deutonymph: Idiosoma L/W 427/350; provisional genital field with two pairs of acetabula.

Remarks: This species was first published from Germany by Piersig (1894) under the preoccupied name $N$. triangularis. It is characterized by a relatively stout $\mathrm{P}-4$ (L/H in males about 3.5, in females 3.1-3.2) with the ventral setae arranged close to each other and without denticles associated to their insertions.

Pešić (2002, 2003a, 2003c) published the presence of Neumania agilis in Montenegro and Macedonia, considering the position of the ventrodistal peg seta on $\mathrm{P}-4$ (distanced from the distal segment edge, see K.Viets 1936b) as a diagnostic feature of this species. 


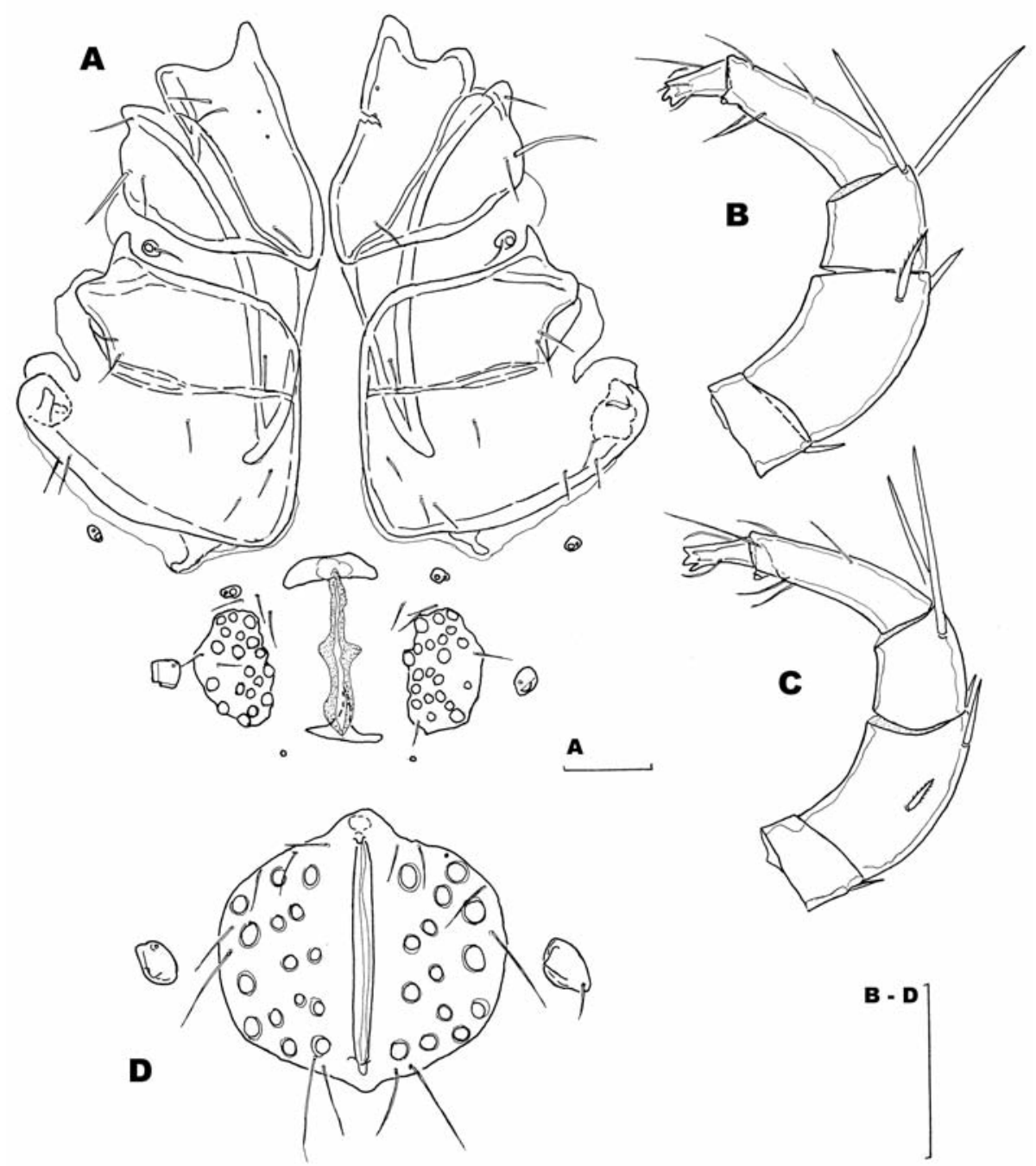

Fig. 1. Neumania deltoides (Piersig), Skadar Lake (A-C female, D male): A = idiosoma, ventral view; $\mathrm{B}=$ palp, medial view; $\mathrm{C}=$ palp, lateral view $\mathrm{D}=$ genital field. Scale bars $=0.1 \mathrm{~mm}$.

From the examination of a larger number of specimens from all over the study area results intraspecific variability of this character.

As also observed by Tuzovskij (pers. communication), deutonymphs of $N$. deltoides have two pairs of Ac, while the Ac number in $N$. limosa deutonymphs is usually 6-7, rarely with 5 pairs. Also larvae of the two species differ clearly: the larval dorsal plate is elongate and rather narrow in $N$. deltoides, but short and wide in $N$. limosa (Tuzovskij, pers. comm.).

Biology: Lenitobiont; mostly restricted to larger pools and lakes.

Distribution: Palaearctic.

\section{Neumania (s.str.) elliptica Walter, 1925}

Records from the Mediterranean: Algeria: Petite Kabylie (Walter 1925, Walter 1928), Wilaya Bechar (Bader 1989); France: Corsica ("N. vietsi" Angelier 1959); Spain: Andalusia (Marazanof 1967), Lerida (Margalef 1948, 1950).

Material examined: France: Corsica, MNHN Paris, Canalli, N. de Bonifacio, 18.08.1950 E.Angelier, slides 2164, 2165, 2167 (1/2/0); F 23 Sarténe (2A). Roccapina. F. Ortolo near Pont de l'Ortolo, $20 \mathrm{~m}$ asl, $8^{\circ} 51 \mathrm{E}, 41^{\circ} 33 \mathrm{~N}, 26.09 .1991$ (1/0/0); F 113 Bonifacio, Rau. de Saparelli near R.N. 198, 16.08.1993 Pusch (0/2/0); Italy: Sicily: I 146 Trapani (TP), T.Lenzi at 

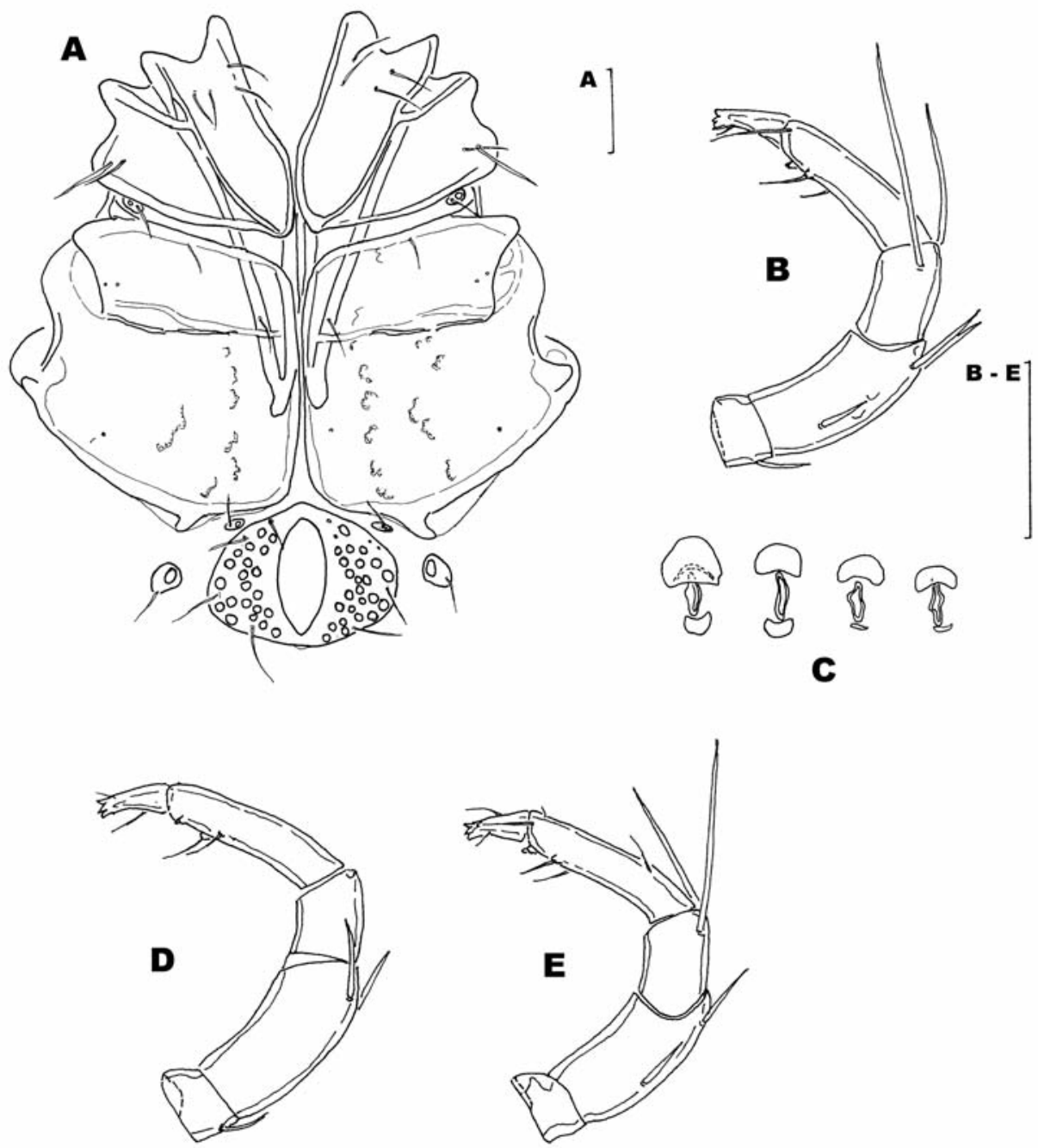

Fig. 2. Neumania elliptica Walter, male (A-C = F 23 Sarténe, D-E = I 1163 Muravera): A = idiosoma, ventral view; $\mathrm{B}=$ palp, lateral view; $\mathrm{C}=$ excretory pore (F23, I 1163, I146, I 373 respectively), D = palp, medial view; $\mathrm{E}=$ palp, lateral view. Scale bars $=0.1 \mathrm{~mm}$.

bridge S.S.113, $40 \mathrm{~m}$ asl, TC $893089,01.09 .1985$ (0/1/0); I 195 Iblei (SR), Rosolini Cava Candelaro, 60 m asl, VA 982 778, 30.09.1985 (0/1/0); I 1068 Iblei (RG), F. Irminio upstr. Ragusa, 150 m, 10.05.1990 (0/1/0); Sardinia: I 1163 Muravera (CA), S. Vito, Flumendosa at $\mathrm{M}$. Perdosu, $15 \mathrm{~m}$ asl, NJ 4370 , 16.09.1991 (3/0/1); I 373 Gallura (SS) R.Piatu at bivio La Maciona, $210 \mathrm{~m}$ asl, NL 23 35, 23.05 .1986 (0/3/0); I 376 Gallura (SS), Telti, R. Taroni upstream Telti, 320 $\mathrm{m}$ asl, NL 27 26, 25.05.1986 (1/1/0). These data include the first record of the species from France (Corsica - here until now confused with $N$. vietsi - see below) and Italy (Sardinia, Sicily).
Description (original description and from Walter 1928, additional data from the examined material): Integument smooth; genital field with 32-36 pairs of Ac; excretory pore associated to a sclerite dot located at the posterior edge of the pore slit and occasionally a further sclerite dot at the anterior edge (Fig. 2 C), never completely surrounded by a sclerite ring; swimming setae numbers (specimens from Corsica and Sardinia, no difference between sexes, $a=$ anterior, $p=$ posterior surface): I-L-5 p 1; II-L-4 p 1, II-L-5 p 1; III-L-3 p 1, III-L-4 p 3-5, III-L-5 p 3-5; IV-L-3 p 2-3, a 1-2, IV-L4 p 5-7, a 2-4, IV-L-5 p 4-8, a 1-3. Palp: distoventral seta associated with well developed denticle-like 
extension, proximoventral seta without denticle associated to it insertion (see Figs. 2 B, D-E).

Male: Idiosoma L/W 930/750); coxal field L 575; genital field (Fig. 2 A) L 172-184, W 219-222, with 2529 acetabula on each side. Palp total L 332-347; dorsal $\mathrm{L}$ and relative $\mathrm{L}$ (\% of total $\mathrm{L}$, in parentheses) of palp segments following Walter (1929) P-1 31, P-2 117, P-3 $60, \mathrm{P}-4$ 123, P-5 44, in our specimens a little smaller, but no differences in proportions: P-1 23-28 (6.9-8.1), P-2 106-111 (31.9-32.0), P-3 53-58 (16.0-16.7), P-4 108-112 (31.1-33.7), P-5 38-42 (11.4-12.1); P-2/P-4 ratio 0.95-1.03; legs dorsal L measurements: I-L-1 7080, I-L-2 122-141, I-L-3 153-172, I-L-4 241-247, I-L5 281-306, I-L-6 278-288; IV-L-1-100, IV-L-2 169187, IV-L-3 231-234, IV-L-4 281-297, IV-L-5 288309 , IV-L-6 275-300. As in the palp, also leg dimensions of the type are larger (I-L-5 340, I-L-6 365; IV-L5 325, IV-L-6 340).

Female: Idiosoma L/W 1170/990; coxal field L 681-700; genital plates L 131-141, W 96-97, with 2834 acetabula on each side. Palp total L 396-410; dorsal $\mathrm{L}$ and relative $\mathrm{L}$ (\% of total $\mathrm{L}$, in parentheses) of palp segments in the type P-1 35, P-2 140, P-3 75, P-4 135, $\mathrm{P}-550$, in our specimens a little smaller, but no differences in proportions: P-1 30-31 (7.6), P-2 129-130 (31.6-32.6), P-3 65-72 (16.4-17.6), P-4 127-130 (32.131.7), P-5 45-47 (11.4-11.5); $\mathrm{P}-2 / \mathrm{P}-4$ ratio $1.0-1.02$; legs dorsal L measurements: I-L-1 78-81, I-L-2 168175, I-L-3 203-225, I-L-4 284-297, I-L-5 303-319, IL-6 297-306; IV-L-1 125, IV-L-2 175-183, IV-L-3 244-250, IV-L-4 312-322, IV-L-5 337-350, IV-L-6 312-326.

Remarks: This species has found little attention since its first description. The excretory pore not completely surrounded by a sclerite ring is well visible in Walter's fig. 17 b (1925), but has not been recognized so far as most important diagnostic character of $N$. elliptica. The leg setation differs from that of $N$. uncinata in the presence of a swimming seta on the anterior surface of IVL-3, and higher numbers of swimming setae on the posterior surface of both IV-L-4 and IV-L-5. As pointed out by Walter (1928), the Ac number of 5 pairs in deutonymphs is rather stable, but we find also specimens with only $4 \mathrm{Ac}$ on one side.

All slides of this species in coll. E.Angelier are labeled as N. elliptica. Obviously, later he changed opinion and published his records from Corsica under the name of $N$. vietsi, possibly induced by the position of the ventrodistal peg-like seta on P-4 distanced from the distal segment edge. However, his own figures testify for the variability of this character. The distanced inser- tion of the ventral setae on P-4 and their association with a denticle suggest that this species is a synonym of $N$. vernalis. However, in view of the absence of information concerning important character states and the lack of type material, it is impossible to give a definitive judgement. Thus, $N$. vietsi should be considered a species incerta. As the diagnostic features of this species were uncertain up to now, the second record from Algeria (Bader 1989) remains unclear - no specimens from the site published by Bader are deposited in the collection of NHMB.

Biology: Characteristic colonizer of pools in summer-warm lowland streams with silty substrata. No records from standing waters.

Distribution: SW-Mediterranean.

\section{Neumania (s.str.) limosa (Koch, 1836)}

Syn.: Neumania (s.str.) agilis Koenike, 1916 (Lundblad 1962a)

Records from the Mediterranean: France: Dauphine, Ile du Titan, Savoie, Touraine, Var (Motaş 1928), Pyrenees-orientales (Motaş \& Angelier 1967); Italy: FriuliVenezia Giulia (Stammer 1932), Lombardia (Maglio 1903, 1924, 1949), Piemonte (Ramazzotti 1947, Nocentini 1966), Veneto (Berlese 1886); Macedonia: Lake Ohrid (Georgevitsch 1906, Stankovic 1931, Georgiev 1957; Pešić 2003a), Skoplje (Schwoerbel 1963; partly as N. agilis - Pešić 2003a); Montenegro: Skadar Lake (partly as N. agilis - Pešić 2002, 2003c), Pešića Lake (Pešić 2004); Slovenia: Postojna (K. Viets 1933); Spain: Aragon, Castilia (K. Viets 1930), Lerida (Margalef 1950), Sierra de Guadarrama (Valdecasas \& Camacho 1986).

Material examined: Italy: I882 Ronciglione (UT) Lago di Vico, riva Nord 507 m asl., 31.07.2000 Phragmites leg. Di Sabatino, Gerecke \& Di Sabatino (2/1/0).

Material compared: SMF, K.Viets, Germany: Bremen, Torfkanal, 46162 \#f; Holstein, Einfelder See, Lenz 03.08.1921 46155 \#f; Harz, Reuschteich, Kühne 02.08.1910 46153 \#m; Bodensee, K.O.Viets 53313 \#f, 53314 \#m; Schwarzwald, Feldsee 53300 \#m, Großer Plöner See 53301, \#m, \#f, 53302 \#m, \#f; Süderbäke, 12.05.1959, K.O.Viets "N. agilis" 1908 \#m, 1909 \#f; Cechia: Böhmen, Voitersreuth, Diener 46143 \#f; France, Castillon Tarnos (Landes), 31.08.1949 "N. agilis" Angelier 46096 \#f; Russia, Königsberg, 20.04.1902 K.Viets "N. agilis" 2041 \#m; Spain, Zaragoza, Balsa de Canas, 07.03.1919 46154 \#f, Casablanca, 12.04.1918 46157 \#f , Torre Pilar, 20.06.1919, 46158 \#m, \#f, Condesa, 25.04.1919 46159 \#m, \#f. 


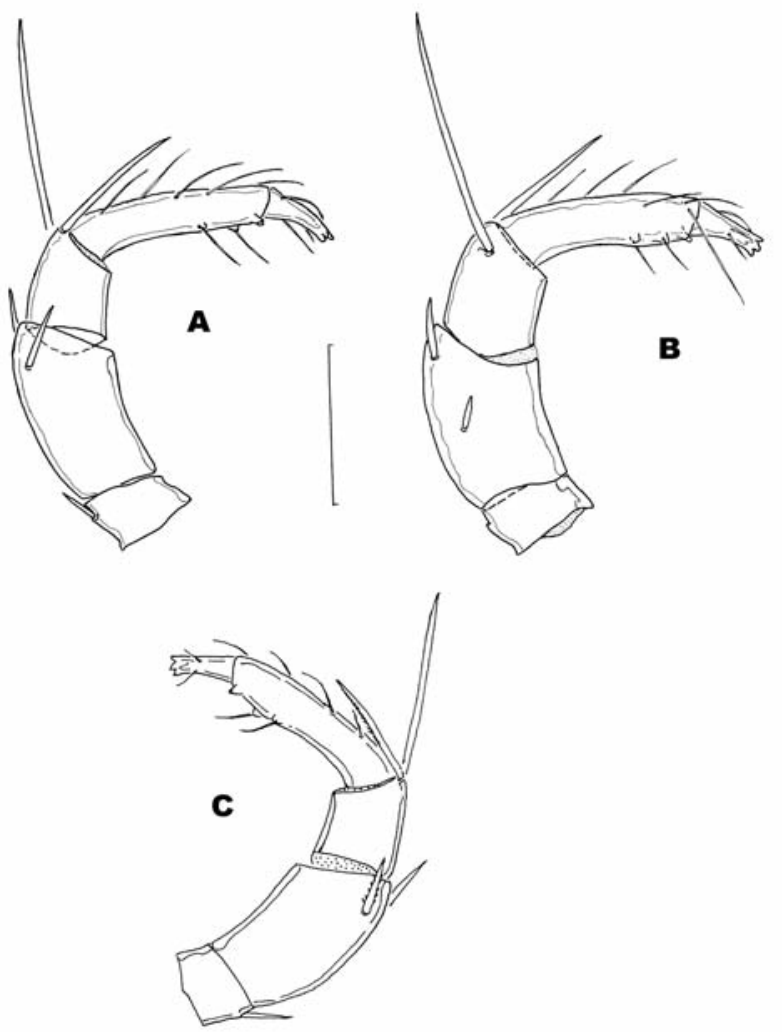

Fig. 3. Neumania limosa (Koch), male (A-B = Lago di Vico, $\mathrm{C}=$ Skadar Lake) $: \mathrm{A}=$ palp, medial view; $\mathrm{B}=$ palp, medial view; $\mathrm{C}=$ palp, lateral view. Scale $\mathrm{bar}=0.1 \mathrm{~mm}$.

Remark: Neumania limosa is characterized in first line by the shape of the palp (P-4 relatively slender $(\mathrm{L} / \mathrm{H}$ males $>4.0$, females $>3.5)$ with ventral setae distanced from each other, associated with well developed denticle-like extensions - see Figs. 3 A-C). The specimens from Lago di Vico differ from other populations in in lower Ac numbers (male 29, female 23 pairs).

Neumania agilis, described from Germany, was later recorded also from France, Latvia, Poland, Montenegro and Macedonia. Following K.Viets (1936b), this species should be characterized by (1) the distal peglike seta on P-4 distanced from the distal segment margin and close to the distoventral seta, (2) the medial dorsodistal seta on P-2 as long as segment P-3 and (3) obtuse angled caudal margins of $\mathrm{Cx}-4$. Neumania agilis has been rarely recorded from single specimens only since the first description, and also a detailed revision of all available specimens (K.O.Viets 1961) did not produce a clear account of diagnostic characters. Lundblad (1962a) proposed to consider N. agilis a synonym of $N$. limosa. This point of view is supported by our comparative study of new material from the mediterranean area and older slide material from Central Europe: In populations of $N$. limosa, specimens are found regularly which have the distal peg seta on P-4 more or less set off from the distal segment margin. A clearcut separation between specimens with this seta placed distally resp. proximally is impossible and this character state is obviously not correlated with the other characters listed above. There is considerable variability in the shape of the posterior margin of $\mathrm{Cx}-4$, and the length of the dorsodistal seta is similar as the length of P-3 also in typical $N$. limosa. From the reexamination of the collection material at SMF results that also K. and K.O.Viets occasionally classified specimens as $N$. limosa which bear a P-3 with ventrodistal seta clearly distanced from distal segment edge. Often, due to weak sclerotisation in the distal part of P-3 it is difficult to distinguish membranous and sclerotized parts in this area. Our observations agree with the proposal of Lundblad (1962a), to consider N. agilis a junior synonym of $N$. limosa.

Biology: Common in eutrophic to dystrophic standing waters, rare in pools of slowly flowing waters and limnocrenes.

Distribution: Palearctic.

\section{Neumania (s.str.) imitata Koenike, 1908}

Records from the Mediterranean: Italy: Lombardia (Maglio 1949); Montenegro: Spuž (Pešić 2003d).

Biology: In lakes and slowly flowing waters.

Distribution: France, Germany, The Netherlands, Italy, Montenegro. Very rare and localized.

\section{Neumania (s.str.) phreaticola (Motaş \& Tanasachi 1948)}

Records from the Mediterranean: Bosnia-Herzegowina (Motaş et al. 1948); France, Corsica: Nord (Angelier 1959), Sud (Santucci 1970, 1971).

Material examined: Italy: Sicily: I 646 I Peloritani (ME). Francavilla T.S.Paolo near B.P.Torre, interstitial dig, $480 \mathrm{~m}$ asl, WB 100 990, 19.06.1988 (0/1/0); Sardinia: I 1165 I Gerrei (CA). Dolianova. R. Lassini/C. Porru, interstitial dig, $380 \mathrm{~m}$ asl, NJ 21 64, 17.09.1991 (0/1/0); France: Corsica: Murato (Bastia) (2B). Bevinco/Mulino alle Noci, interstitial dig, $310 \mathrm{~m}$ asl, $09^{\circ} 21 \mathrm{E}, 42^{\circ} 35 \mathrm{~N}, 03.10 .1991(0 / 1 / 0)$; Slovenia: KRI026/A3, Želimeljščica River, hyporheic zone, 5082311 N, 5469014 E, 345 m asl, 08.05.2002, (0/0/1, cf. phreaticola); KRI035/A3, Želimeljščica River, hy- 


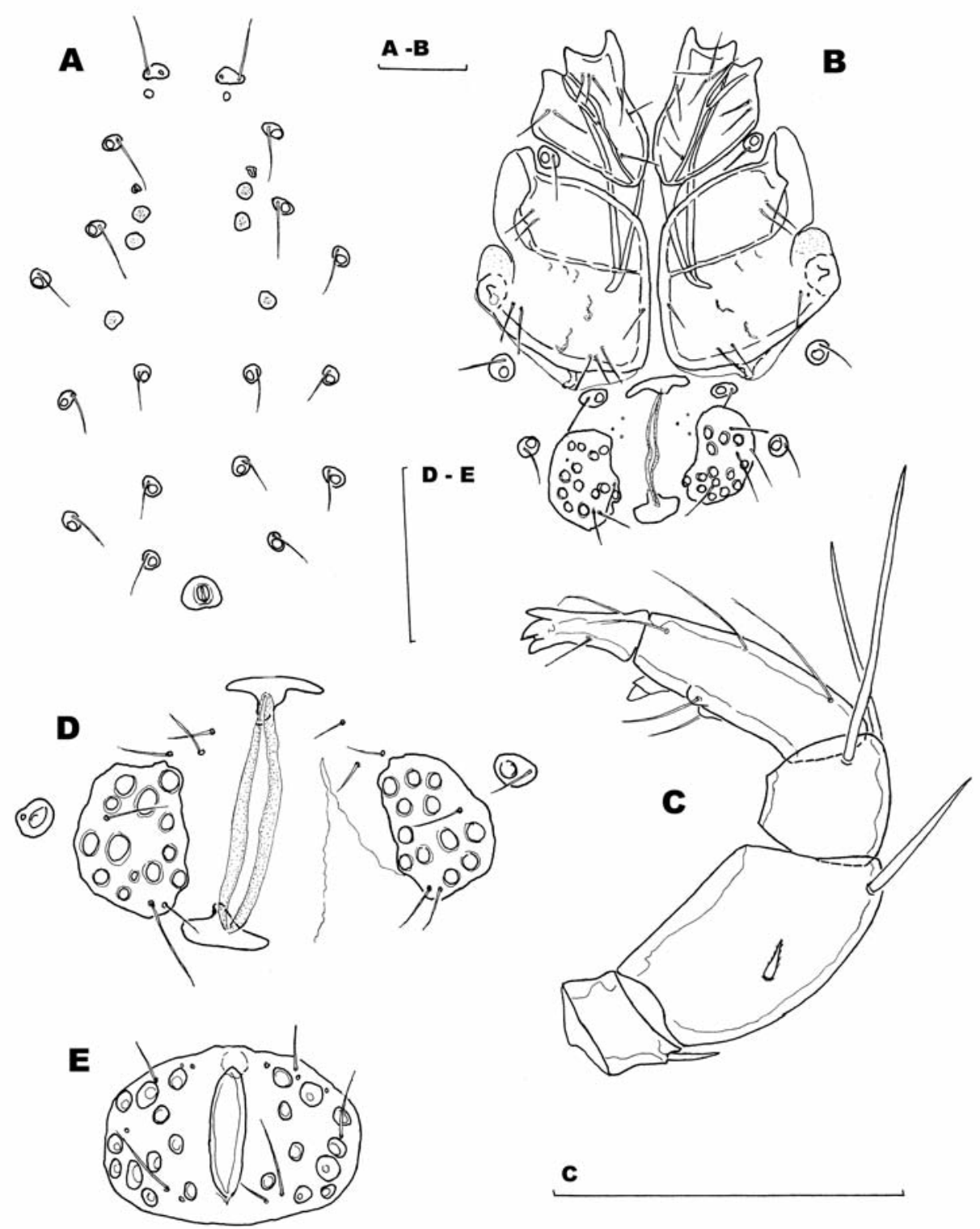

Fig. 4. Neumania phreaticola $(\mathrm{A}-\mathrm{D}=$ female, Corsica $\mathrm{E}=$ male, Slovenia $)$ : $\mathrm{A}=$ idiosoma, dorsal view; $\mathrm{B}=$ idiosoma, ventral view; $\mathrm{C}=$ palp, lateral view: $\mathrm{D}=$ genital field; $\mathrm{E}=$ genital field. Scale bars $=0.1 \mathrm{~mm}$.

porheic zone, $5088450 \mathrm{~N}, 5466500 \mathrm{E}, 297 \mathrm{~m}$ asl, 30.05.2002, (0/1/0), KRI 086/B4 Iška River, phreatic zone, $5084750 \mathrm{~N}, 5461050 \mathrm{E}, 363 \mathrm{~m}$ asl, 31.05. 2002, (1/0/0), KRI176/D3, Podlipščica River, hyporheic zone, $5094242 \mathrm{~N}, 5443255 \mathrm{E}, 300 \mathrm{~m}$ asl, 17.07.2002 (2/0/0); KRI177/D3, Podlipščica River, hyporheic zone, $5094169 \mathrm{~N}, 5444172 \mathrm{E}, 297 \mathrm{~m}$ asl, 17.07.2002 $(0 / 1 / 0)$. These dates include the first records from Italy and Slovenia.
Diagnosis: Skin with numerous small chitinous spines; dorsum with three pairs of small muscle attachment platelets; excretory pore with well developed secondary sclerotization; genital plates each with acetabula, gonopore longer than genital plates, P-4 with well developed ventro-distally papilla with a chitinous tip.

Description: (specimens from Slovenia) Skin with numerous small chitinous spines; dorsum with three pairs of small muscle attachment platelets (Fig. 4 A); 
excretory pore with well developed secondary sclerotization, lying at posterior end; Palp setation and proportions of segments: Fig. 4 C: P-4 with peg-like seta inserting at ventrodistal edge; number of swimming setae on legs: I-L-1 p 1; II-L-4 p 1, II-L-5 p 1; III-L-3 p 1, III-L-4 p 3, III-L-5 p 3; IV-L-3 p 1-2, IV-L-4 a 3, p 3, IV-L-5 a 3, p 2-3.

Male: coxal field L (distance between anterior end of fist coxae and posterior margin of fourth coxae) 409; Genital field (Fig. 4 E) L/W 109/154, gonopore L 79, 10-11 acetabula on each side; ejaculatory complex L 105; chelicera L 113; gnathosoma L 99; palp $(n=2)$ total L 239, dL and relative L (in parentheses, \% total L) of palp segments: P-1 18-21 (7.6-8.8), P-2 76-78 (31.832.9) , P-3 37-39 (15.6-16.3) , P-4 69-70 (28.9-29.5), P-5 34 (14.2-14.4); P-2/P-4 ratio 1.1.

Female: Idiosoma L/W 580/445; coxal field (Fig. 4 B) L 394-412; genital field (Fig. 4 D) terminal, W 241250 genital plates L/W 93-115/68-79, with $12-15$ pairs of acetabula; gonopore L 147-150. Palp: total L 232$247, \mathrm{dL}$ and relative $\mathrm{L}$ (in parentheses, \% total L) of palp segments: P-1 21-22 (8.81-9.1), P-2 73-79 (31.832.3), P-3 35-39 (15.1-16.3), P-4 70-73 (29.3-30.5), P5 30-35 (12.6-14.2); P-2/P-4 ratio 1.04-1.09; chelicera total L 112-115. Legs: dorsal L of the first leg: I-L-1 44-56, I-L-2 74-82, I-L-3 91-96, I-L-4 118-127, I-L-5 126-135, I-L-6 153-168; dorsal L of the fourth leg: IVL-1 65-68, IV-L-2 88-100, IV-L-3 106-115, IV-L-4 141-156, IV-L-5 165-176, IV-L-6 168-179.

Remarks: Compared with the original description, specimens from Tyrrhenian islands differ in the presence of three distinct pairs of small platelets on the dorsum (two pairs of platelets in original description). Intermediate features in a specimen from Iran (Pešić et al. 2005: two and three pairs of platelets on left and right side of the dorsum, respectively) suggest that these differences represent individual variability rather than interspecific genetic differences.

Biology: Hyporheobiont.

Distribution: Southern Europe, Iran.

\section{Neumania (s.str.) seurati Walter, 1931}

Neumania algeriensis Bader, 1989, nov. syn.

Material examined: Holotype male: Algeria, Hoggar (Gauthier 1931) NHMB «Sahara, Imamera coll. Seurat 24.3.28» (gnathosoma, idiosoma on two slides). Paratype female, same locality as holotype (gnathosoma, idiosoma on two slides). Paratype female, Algeria, Hoggar, Tin/Ikert, coll. Seurat 17.4.28. From this site also one deutonymph, not designated as belonging to the type series. Central Sahara: SMF 46222, Adessi, Vaillant leg. 1949, 1 female, SMF 53395, Guelta tombe Garamantique, Vaillant leg. 1949, 1 female. Neumania algeriensis, holotype male, Algeria, Wilaya Bechar, 4.5.1983 "Algerien 28". Paratypes, same site and date as holotype $(8 / 5 / 2)+2$ slides with dissected appendages belonging to several paratypes.

Records from the Mediterranean: Algeria: Central Sahara (K. Viets 1951), Wilaya Bechar (sub nom. N. algeriensis - Bader 1989).

Description: Integument covered by fine denticles in hexagonal arrangement; Cx-IV with extensions near the insertion of IV/L rather stout, not bent caudally, and caudal extensions directed laterally genital field with 12-18 pairs of Ac; Palp (Fig. 6 A-B) measurements in specimens $(\mathrm{n}=4)$ from the type series of Neumania algeriensis were found as follows (without difference between sexes): palp total L 295-343; dorsal L and relative $\mathrm{L}$ (\% of total $\mathrm{L}$, in parentheses) of palp segments: P-1 26-30 (8.8-9.0), P-2 87-103 (29.8-30.0), P-3 50-64 (17.0-18.7), P-4 95-106 (30.9-32.2), P-5 33-40 (11.612.4); P-2/P-4 ratio 0.93-0.97.

Male: Idiosoma L/W 531-594/363-462; coxal field L 403-456; genital field (Fig. $5 \mathrm{~A}$ ) transverse oval, anteriomedially slightly extending between medial margins of Cx-IV, with rather small acetabula and extended interspaces, L/W 203-241/109-127; legs dorsal L measurements: I-L-1 53-56, I-L-2 94-106, I-L-3 122131, I-L-4 181-188, I-L-5 200-202, I-L-6 195-203; IVL-1 75-87, IV-L-2 109-113, IV-L-3 128-134, IV-L-4 183-195, IV-L-5 214-222, IV-L-6 222-237.

Female: Idiosoma L/W 613/463; coxal field L 469472; genital field (Fig. 5 B) W 238-281, genital plates L 122-156, W 66-91; legs dorsal L measurements: I-L1 50-63, I-L-2 113-122-, I-L-3 147-153, I-L-4 219225, I-L-5 234-241, I-L-6 203-209; IV-L-1 103-109-, IV-L-2 119-128, IV-L-3 153-166, IV-L-4 219-236, IVL-5 259-266, IV-L-6 253-272.

Remarks: Neumania seurati is similar to $N$. uncinata in the integument covered by denticles, but differs in their dimensions and arrangement (in $N$. uncinata larger, not arranged in a hexagonal pattern, but forming a dense pelt). Further differences regard the extension near the insertion of IV/L (in N. uncinata less stout and generally bent caudally), the caudal extension of fourth coxae (in $N$. uncinata long and parallel to the medial axis) and the shape of the male genital field (in N. uncinata subtriangular, with relatively larger acetabula and little extended interspaces).

From the original description of $N$. algeriensis results that Bader was aware about the similarity with 


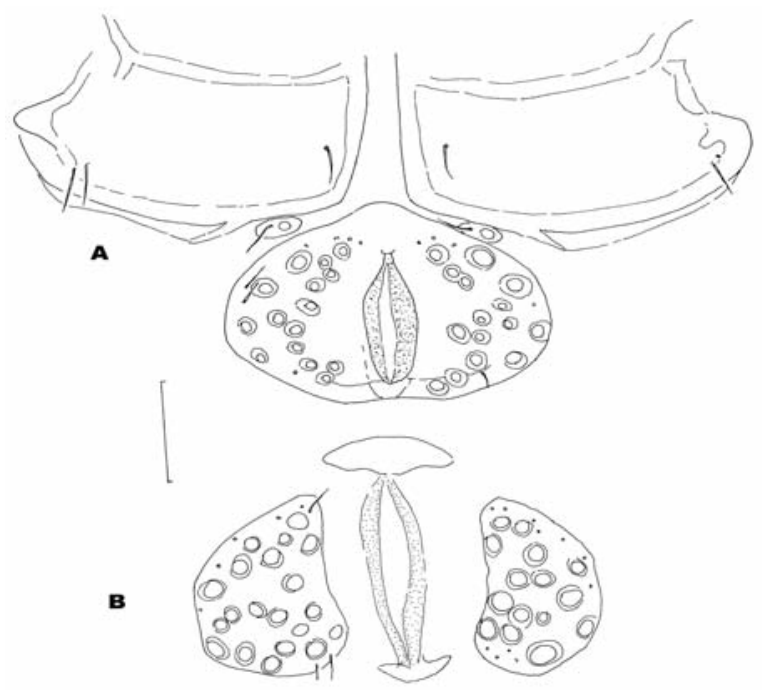

Fig. 5. Neumania seurrati Walter (A male holotype, B female paratype): $\mathrm{A}=\mathrm{Cx}-4$ and genital field; $\mathrm{B}=$ genital field. Scale bar $=0.1 \mathrm{~mm}$.

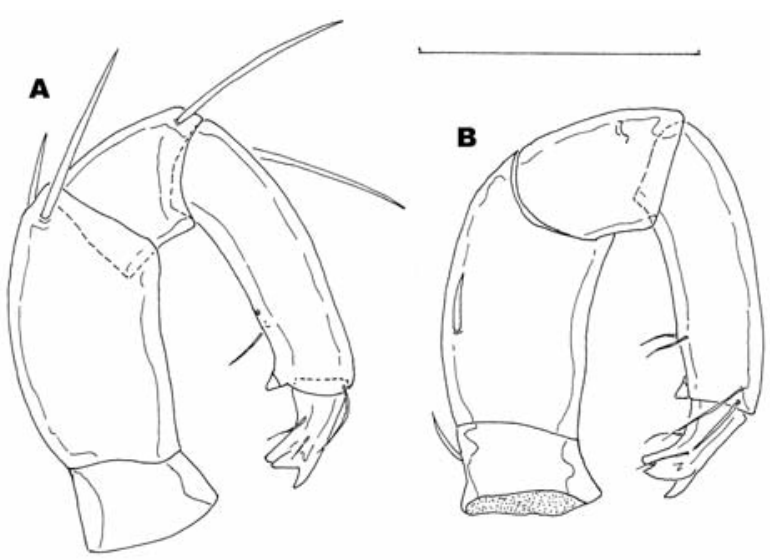

Fig. 6. Neumania seurrati Walter (male from type series of N. algeriensis): $\mathrm{A}=$ palp, medial view: $\mathrm{B}=$ palp, lateral view. Scale bar $=0.1 \mathrm{~mm}$.

$N$. seurati. The only differences he regarded of importance are not suitable for separating species in this genus. As just mentioned by K.O.Viets (1961), the relative length of the mediocaudal apodemes extending from the first coxal plate (ending at the posterior edge of Cx-III or extending to the centre of CX-IV) is highly depending both on age, and on squeezing in slidemounted specimens. Also in the type series of N. algeriensis, a wide variability is found. In the important characters (shape and arrangment of skin denticles, extensions of CX-IV and male genital field, the specimens of the type series agree well with the type series of
$N$. seurati. Differences in slightly larger dimensions of the holotype of $N$. seurati (coxal field L 521, genital field L 275, palp total L 346) are surely of no taxonomical significance.

Biology: Wells.

Distribution: Algeria.

\section{Neumania (s.str.) spinipes (Müller, 1776)}

Records from the Mediterranean: France: Dauphine, Var (Motaş 1928); Italy: Lombardia (Maglio 1905), Veneto (Largaiolli 1901); Serbia: Belgrade (Georgevitsch 1903).

Material examined: Italy: Sicily: I 96 Nebrodi (ME). Monte Soro limnocrene N slopes, $1300 \mathrm{~m}$ asl, VC 73 00 (1/0/0); I 117 Nebrodi (EN). Monte Sambughetti, laghetto Campanito, $1257 \mathrm{~m}$ asl, VB 46 87, 07.08 .1985 $(1 / 6 / 2)$.

Biology: Common in eutrophic to dystrophic standing waters of central Europe; the records from mountain lakes and limnocrenes in Sicily refer to isolated populations at the far Southern margin of the distribution area.

Distribution: Holarctic.

\section{Neumania (s.str.) uncinata Walter, 1927}

Neumania atlantida Lundblad, 1962, nov. syn.

Records from the Mediterranean: France: Provence (Motaş 1927), Pyrenées-orientales (Motaş \& Angelier 1967), Var (Motaş 1928); Portugal: Cintra, (Lundblad 1956); Canary islands, Gomera ("N. atlantida" Lundblad 1962b); Spain: Aragon (K. Viets 1930), Baleares (Valdecasas \& Aviles 1983), Salamanca (Lundblad 1956), Valencia (K. Viets 1930).

Material examined: Bosnia and Herzegovina: YU 15 Trebinje (TB), Lastva. Nudoljska Rijeka, $550 \mathrm{~m}$ asl, $42^{\circ} 47 \mathrm{~N}, 16^{\circ} 10 \mathrm{~W}, 02.06 .1990$ (1/2/0); France: Corsica: F 34 Corte (2B), San Gavina, Rau de Felce, $550 \mathrm{~m}$ asl, $09^{\circ} 09 \mathrm{E}, 42^{\circ} 16 \mathrm{~N}, 30.09 .1991$ (1/0/0); F 35 Calacuccia (2B), Castirla, spring E slopes Capo d'Alici, $390 \mathrm{~m}$ asl, $09^{\circ} 08 \mathrm{E}, 42^{\circ} 23 \mathrm{~N}, 30.09 .1991$ (1/0/0); F 52 Calacuccia (Corte) (2B), Fango "below station", 13.05.1989 Schwoerbel \& al. (0/2/0); F 88 Porto (2B), Rau. d'Enova N Crète d'Andatone, 390 m asl, 08.06.1993 (0/1/0); Greece: Makedonia: GR 38 Chalkidiki, Chlomón Oros, valley at southern slopes, $650 \mathrm{~m}$ asl, QU 32 16, 29.05.1991 (0/2/0); GR 45 Xanthi, NE pass road Xanthi-Stavrupolis, $800 \mathrm{~m}$ asl, RL 47 97, 31.05.1991 (7/4/0); Kiklades: GR 49 Naxos, Apolonas, ca. 2 km 
from $\mathrm{N}$ coast, $80 \mathrm{~m}, 11.05 .1990$ Potthast (0/1/0); GR 50 Naxos, Apiranthos, spring pool $100 \mathrm{~m}$ below village, $400 \mathrm{~m}$ asl, 11.05.1990 Potthast (0/3/0); Dodekanes: GR 57 Kos, mountain village Pili, spring above military camp, $250 \mathrm{~m}$ asl, $27^{\circ} 10^{\prime} \mathrm{E}, 36^{\circ} 50^{\prime} \mathrm{N}$, 25.03.1991 Potthast (2/6/0); GR 79, Kreta, Sarakinos valley near Mithi, 3-5 km N Mirthes, 01.10.1995 Potthast. Israel: IS or 26 Golan, Nahal Meshushim st. 20, 15.07.1986, Ortal (IES 5088 Aca 1757) (1/3/0); IS or 36 , as IS or 26, 10.09.1986 (IES 5179 Aca 1767) (0/2/0); IS or 38 Golan, En Mazad st. 1, 10.12.1987, Ortal (IES 5165 Aca 1849) (1/4/0); IS or 69 Golan, Nahal Samakh st. 10, 17.03.1986, Ortal (IES 5026 Aca 1801) (1/1/0); En Teo Canal, 12.12.2004, Dimentman (1/0/0); N Orevim, 19.03.2004 Dimentman (1/0/0); IS or 86 Sinai, Sta. Catherina, 06.09.1968 Margalit (0/1/0). Italy: Sicilia: I 2 Iblei (SR), Cava del Carosello, pool, $340 \mathrm{~m}$ asl, WA 01 88, 20.04 .1985 (0/3/0); I 39 Iblei (SR), Sortino, F.Anapo, contrada fiumara di sotto, pool, $185 \mathrm{~m}$ asl, WB 03 10, 02.05 .1985 (1/0/0); I 46 Marineo (PA). F.Eleuterio upstr. purification plant, pool, $250 \mathrm{~m}$ asl, UC 601 031, 30.05 .1985 (1/1/0); I 98 Iblei (SR), T. Sta. Chiara at bridge S.S.287, pool, 300 $\mathrm{m}$ asl, WA 04 88, 13.07.1985 (1/0/0); I 99 Iblei (SR), Noto antica, Cava del Carosello, pool, $300 \mathrm{~m}$ asl, WA $0187,14.07 .1985$ (6/1/9); I 165 Madonie (PA), T. Isnello upstr. Isnello, pool, $600 \mathrm{~m}$ asl, VB 120994 , 11.09.1985 (1/0/0); I 168 Madonie (PA), Pollina valley, T.Grosso below C.Parissi, $350 \mathrm{~m}$ asl, VB 278935 , 12.09.1985 (0/1/0); I 181 Iblei (SR), Avola antica, F. Manghisi in Cava Grande, pool, $225 \mathrm{~m}$ asl, WA 085 919, 19.09.1985 (0/0/1); I 185 Peloritani (ME), Antillo, spring in Contrada Castagna, $590 \mathrm{~m}$ asl, WC 193 040, 24.09.1985 (0/0/1); I 199 Peloritani (ME), Altolia, stream upstr. Altolia, pool, $315 \mathrm{~m}$ asl, WC 387 147, $06.10 .1985(0 / 1 / 0)$; I 205 Partinico (PA) F.Iato above S.S. 113, 170 m asl, UC 313 099, 15.10 .1985 (1/0/0); I 213 Etna (CT), Adrano, Ferro di Cavallo at S. Domenico, $260 \mathrm{~m}$ asl, VB 822 707, 26.10.1985 (0/1/0); I 250 Iblei, Sortino (SR), Cava Grande in contrada Foresta, pool, 450 m asl, VB 95 10, 22.11.1985 (9/9/0); I 282 Piana degli Albanesi (PA), Lumi i Varfrit, $620 \mathrm{~m}$ asl, UC 507 063, 28.03.1986 (0/1/0); I 318 Iblei (RG), M.Lauro, Vallone Donninga, $750 \mathrm{~m}$ asl, VB 843 099, 15.04.1986 (0/2/0); I 470 Sicani (PA), Contessa Entellina, T.Realbate at ponte Alvano, $360 \mathrm{~m}$ asl, UB 43 78, 25.08.1986 (1/2/1); I 467 Sicani (PA), Giuliana T.Landro at S.S.188, interstitial dig, $410 \mathrm{~m}$ asl, UB 38 76, 24.08 .1986 (1/1/0); I 531 (ME) Peloritani, S. Lucia, spring near Fiumara di Floresta, $430 \mathrm{~m}$ asl, WC 198 097, 5.11.1986 (0/0/1); I 540 Nebrodi (ME), Caronia, Pizzo Michele, Case Finocchio, $500 \mathrm{~m}$ asl, VC 572 075, 28.11.1986 (2/13/1); I 542 Nebrodi (ME), Caro- nia, Pizzo della Luna, $620 \mathrm{~m}$ as1, VC 572067 , 28.11.1986 (2/3/1); I 573 Peloritani (ME), S.Lucia del Mela, F.di Floresta, contrada S.Venera, $450 \mathrm{~m}$ asl, WC 20 09, 16.09 .1987 (0/4/0); I 1068 Iblei (RG), F. Irminio upstr. Ragusa, $150 \mathrm{~m}$ asl, 10.05.1990 (0/2/0); Sardinia: I 381 Villanova Monteleone (SS) R.Lacanu at S.S.292, $400 \mathrm{~m}$ asl, MK 50 81, 28.05 .1986 (2/1/0); I 389 Gerrei (CA). Dolianova. R. Lassini / road to S.Nicolo, interstitial dig, $800 \mathrm{~m}$ asl, NJ 22 65, 01.06 .1986 (1/3/0); I 1164 S. Nicolò Gerrei (CA), R. Marrada in C. Aresu, 350 m asl, NJ 24 68, 16.09.1991 (0/1/0); I 1165 Gerrei (CA), Dolianova. R. Lassini near Case Porru, 380m, NJ 21 64, 17.09.1991 (1/0/0); I 1175 Bosa (NU), Riu Mesu NW Montresta, 270 m, MK 57 70, 22.09.1991(0/0/1); I 1183 R. Pirastru at M. Ruiu (SS) (road VillalbaS.Teresa), $50 \mathrm{~m}$ asl, ML 97 39, 25.09 .1991 (0/4/0); Montenegro: Podgorica (PG), stream Rimanić near Martinići village, $45 \mathrm{~m}$ asl, 23.10.2004, Pešić (0/1/0); Spain: Andalusia: E 115 Alcornocales (CA), spring area NE Puerto de Galiz, 460 m asl, TF 67 49, 03.04.1994 (0/3/0); E 121 Sierra del Endrínal (CA), Rio Guadalete W Grazalema, $900 \mathrm{~m}$ asl, TF 86 71, 09.04.1994 (2/3/0); Murcia: E 128 Aragon, Horta de San Juan, Faixa de la Carrasca N Mas de Josepó, Rheocrene, $650 \mathrm{~m}$, 17.04.1998 (0/1/0); E 168 Sierra del Segura, R. Benámor NW Moratella, $700 \mathrm{~m}$ asl, 17.04 .1999 (0/1/0). E 172 Canary islands, Teneriffa, Parque rural Anaga, Las Mercedes, S Ermita Cruz del Carmen, ca. 900 m, 14.05.2005 Allgaier (0/1/0); E 180 Canary islands, Gomera, Bosque El Cedro, Pajarito, sauthern stream Bach, ca. $1200 \mathrm{~m}, 20.03 .2006$ Allgaier (0/15/1). These data include the first records from Greece, Italy, Bosnia and Herzegovina and Montenegro.

Remarks: Swimming setae numbers in specimens from Greece and Israel were found as follows (without difference between sexes, $a=$ anterior, $p=$ posterior surface): I-L-5 p 1; II-L-4 p 1, II-L-5 p 2; III-L-3 p 1, III-L-4 p 4, III-L-5 p 3-4; IV-L-3 p 2, IV-L-4 p 3, a 2, IV-L-5 p 2-3, a 1-2. In one male from Israel (N Oravim), the margins of the genital sclerites and of the posterior Coxae IV are extended by secondary sclerotization. Unpublished documents in the heredity of C. Davids show that he, after revising the types of $N$. atlantida, came to the result that this species should be a junior synonym of $N$. uncinata. Our observations on a more extended material from Gomera result in an identic conculsion. As pointed out above, the relative extension of the apodemes originating form $\mathrm{Cx}-\mathrm{I}$ is highly variable. Furthermore, the important character state of the Cx-IV, with lateral extensions near leg insertions fine and pointed, often bent caudally, is found expressed similarly in continental and insular populations. 
Biology: Our rich material from springs and running waters demonstrates that $N$. uncinata in the Mediterranean area preferably inhabits pool areas with sand or gravel substrata in rivers and streams in lowland or at middle elevations.

Distribution : Mediterranean.

\section{Neumania (s.str.) vernalis (Müller, 1776)}

Records from the Mediterranean: France: Dauphine, Jura (Motaş 1928); Herault (Lundblad 1956), HteLoire, Puy-de-Dôme (Motaş \& Angelier 1967); Italy: Lombardia (Maglio 1924, Nocentini 1963), Piemonte (Ramazzotti 1947, Nocentini 1960, 1966, 1979); Macedonia: Ohrid (K.Viets 1936a; Besseling 1957; Georgiev 1957; Pešić 2003a); Serbia: Belgrade (Georgevitsch 1903) .

Biology: Common in eutrophic to dystrophic standing waters.

Distribution: Palearctic; in Europe mostly restricted to areas of temperate and cold climate, with the records from Macedonia as the southernmost extension of the distribution area.

\section{Neumania (s.str.) verrucosa (Koenike, 1895)}

Records from the Mediterranean: Serbia: Belgrade (Georgevitsch 1903).

Biology: Stagnant waters, possibly with a preference for groundwater-influenced habitats.

Distribution: E-Central European; very rare.

\section{Subgenus Soarella Koenike, 1907}

\section{Neumania (Soarella) papillosa (Soar, 1902)}

Records from the Mediterranean: Italy: Lombardia (Maglio 1949); Portugal: Coimbra, Guarda (Lundblad 1956); Montenegro: Skadar Lake (Pešić 2002).

Remark: The subgenus Soarella is mostly known from Africa and Orientalis. They are characterized by the location of dorsal glandularia on large, projecting tubercles. This is the only species of the subgenus present outside its almost tropical distribution area.

Distribution: Europe.

\section{Subgenus Subneumania Lebert, 1879}

\section{Neumania (Subneumania) dura K. Viets, 1930}

Records from the Mediterranean: Algeria, Central Sahara, Tassili N'Ajjer (K. Viets 1951).

Remark: Species of the subgenus Subneumania are characterized by extensive sclerotization of the venter in males. Their distribution is restricted to Africa where the area of $N$. dura reaches the southern parts of Algeria.

Distribution: Africa.

\section{Acknowledgements}

A meeting of V. Pešić and R. Gerecke in Podgorica for the preparation of this manuscript found financial support from the DFG (Ge 646/10-1), the material of E. Angelier was investigated during a stay of R. Gerecke at MNHN with support from the EU (Synthesys programe). Peter Jaeger (SMF), Marc Judson (MNHN) and Urs Wuest (NHMB) helped with loan of specimens and hospitality at their museum departments. Furthermore, we are thankful to the collectors Christoph Allgaier (Tübingen), Noah Dimentman, Jose Margalit and Reuven Ortal (Jerusalem), Thomas Potthast (Tübingen) and Martina Pusch (Schöneiche) for providing important material from their field collections. We are thankful to Petr Tuzovskij (Borok) for useful advice, and to Anton Brancelj and Natasa Mori (Cluj) for their support. The water mite communities from Slovenia were sampled during field work for the EU-project PASCALIS (Protocols for the Assessment and Conservation of Aquatic Life In the Subsurface).

\section{References}

Angelier, E. (ed). 1959. - Hydrobiologie de la Corse. Vie et Millieu, Suppl., 8, 1-277.

Angelier E., Dechamps H. \& Rey J. 1963. - Les Hydracariens du Céret; Étude systématique et ecologique. Bull. Soc. Hist. natur. Toulouse, 98 (3-4), 459-500.

Bader, C. 1989. - Wassermilben (Acari: Hydrovolziidae et Hydrachnellae) aus Algerien. Bijdr. Dierk., 59(1), 33-42.

Berlese, A. 1886. - Acari, Myriopoda et Scorpiones hucusque in Italia reperta. Patavii, Firenze, Portici, Band 3 (30), 10.

Besseling A. J. 1957. - Zoological results of a collecting journey to Yugoslavia 1954. 4. Wassermilben. Beaufortia, 61 (5), 179-181.

Cicolani B. \& Di Sabatino A. 1985. - Gli acari acquatici (Hydrachnellae e Porohalacaridae) del Lago Trasimeno ed elenco delle specie raccolte nei laghi italiani. Riv. Idrobiol., 24 (1-2), 41-64.

Cook D. R. (1974). - Water mite genera and subgenera. Mem. Amer. Ent. Inst., 21, 1-860.

Gauthier H. C. 1931. - Faune aquatique du Sahara central. Récoltes du M. L. Seurat au Hoggar en 1928. Bull. Soc. Hist. Nat. Afr. Nord, Alger, 22 (8), 350-400.

Georgevitsch J. Z., 1903. - Beitrag zur Kenntnis der Fauna Serbiens, II.: serb. Hydrachnellae. Ghlas. Serb. Acad. Wiss. Beograd, 67, 153-189. (in serb.)

Georgevitsch J. Z. 1906. - Beitrag zur Kenntnis der Hydrachniden Mazedoniens. Zool. Anz., 30 (24), 769-775.

Georgiev M. L. 1957. - Über die Hydrachniden des Ochridsee-Basins. Folia Balcanica, 1 (8), 39-49.

Gerecke R., Weigmann G., Wohltmann A. \& Wurst E. 2006. - Order Acari-General introduction and key to major groups. Pages 14-57 in Süßwasserfauna von Mitteleuropa, Vol. 7, 2-1. Gerecke, R. (ed.). Spektrum Elsevier.

Largaiolli V. 1901. - Idracne del Benaco. Terzo contributo allo studio delle Idracne italiane. Riv. Tridentum, Trento, fasc. 1, 1-5. 
Lundblad O. 1956. - Zur Kenntnis süd- und mitteleuropäischer Hydrachnellen. Ark. Zool., 10 (1), 1-306.

Lundblad O. 1962a. - Die Hydracarinen Schwedens. II. Ark. Zool., (2) 14 (1), 1-635.

Lundblad O. 1962b - Wassermilben von den Kanarischen Inseln. Ark. Zool., (2) 15 (16), 285-300.

Maglio C. 1903. - Primo elenco d'Idracne del Pavese. Rend. Ist. Lombard. Sci. Lett., Milano (s.2), 36, 291-299.

Maglio C. 1905. - Secondo elenco d'Idracne del Pavese. Rend. Ist. Lombard. Sci. Lett., Milano (s.2), 38, 147-154.

Maglio C. 1924. - Idracarini. Pages 75-124 in La Limnologia del Lario. Monti R. Min. Econ. naz., Roma.

Maglio C. 1949. - Idracarini dello Strona. Studia Ghisleriana, "Studi Medici-Biologici", Pavia, 3 (1), 1-8.

Marazanof F. 1967. - Ostracodes, Cladocères, Hétéroptères et Hydracariens nouveaux pour les marismas du Guadalquivir (Andalousie), données écologiques. Annls. Limnol., 3 (1), 47-64.

Margalef R. 1948. - Primera nota sobre la biologia de las aguas astancadas del bajo Urgel. Inst. Estudios Ilerdenses, Lerida. Rev. Ilerda, 5, 1-65.

Margalef R. 1950. - Segunda nota sobre la biología de las aguas estancadas del bajo Urgel. Rev. Ilerda, 13, 329-375.

Marucci V. 1902. - Nota preliminare sugli Idracnidi del lago di Castel Gandolfo. Monit. zool. ital., 13, 35.

Motaş C. 1926. - Note sur les Hydracariens du Dauphiné. Assoc. franc. avancem. Sci., Grenoble 1925, Zool. Anat., Physiol., 410-412.

Motaş C. 1927. - Hydracariens nouveaux pour la faune francaise. Proc. Verb. Soc. Dauphin. étud. biolog., Grenoble, 5 (97), 1-4.

Motaş C. 1928. - Contribution à la connaissance des Hydracariens francais, particuliérement du Sud-Est de la France. Trav. Labor. Piscicult. Univ. Grenoble, 20, 1-373.

Motaş C. \& Angelier C. 1967. - Quelques Hydrachnellae nouvelles ou rares des Pyrénées Orientales (Acari). - Annls. Limnol., 3 (1), 17-46

Motaş C., Tanasachi J. \& Botnariuc N. 1948. - Sur quelques Hydracariens recueillis en Yougoslavie dans le basin de la Bosna. Bull. École Polytechn. Jassy, 3 (2), 747-774.

Nocentini, A. M. 1960. - Hydrachnellae del Lago di Mergozzo. Mem. Ist. Ital. Idrobiol., 12, 245-287.

Nocentini A. M. 1963. - Strutture differenziali della fauna macrobentonica litorale del Lago Maggiore. Mem. Ist. Ital. Idrobiol., 16, 189-274.

Nocentini A. M. 1966. - Struttura e dinamica della fauna macrobentonica litorale e sublitorale del Lago di Mergozzo. Mem. Ist. Ital. Idrobiol., 20: 209-259.

Nocentini A. M. 1973. - La fauna macrobentonica litorale e sublitorale dei Laghi di Bolsena, Bracciano e Vico (Italia centrale, Lazio). Mem. Ist. Ital. Idrobiol., 30, 97-148.

Nocentini A. M. 1979. - Variazioni temporali e spaziali della fauna macrobentonica litorale del Lago di Mergozzo. Mem. Ist. Ital. Idrobiol., 37, 277-327.

Pešić V. 2002. - Water mites (Acari, Actinedida) of the stagnant waters from the Skadar lake drainage basin (Crna Gora, Yugoslavia). Acta Ent. Serb., 5 (1/2), 131-152.

Pešić V. 2003a. - Water mites (Acari: Hydrachnidia) from Macedonia. Part 2. Stagnant waters. Acta Zool. Bulg., 55 (2), 29-42.

Pešić V. 2003b. - New records of water mites (Acari: Hydrachnidia and Halacaroidea) from Bosnia and Herzegowina, with description of a new species, Aturus gordani. Arch. Biol. Sci., Belgrade 55 (34), 107-112.

Pešić V. 2003c. - On some very interesting water mite species (Acari, Actinedida) from Crna Gora (Montenegro), new for the Balkan peninsula and Mediterranean region. Natura Montenegrina 1, 89-98.
Pešić V. 2003d. - New records of water mites (Acari: Hydrachnidia) from running waters from Montenegro and FYR Macedonia (SE Europe). Acta Ent. Serb., 6 (1/2), 131-128.

Pešić V. 2004. - Water mites (Acari: Hydrachnidia) of the Biogradska Gora National Park (Serbia and Crna Gora). Pages 65-86 in The Biodiversity of the Biogradska Gora National Park. Pešić, V. (ed). Monographies I, Department of Biology, University of Montenegro \& Centre for Biodiversity of Montenegro.

Pešić V., Saboori A., Asadi M. \& Vafaei, R. 2005. - Water mites (Acari: Hydrachnidia) from interstitial waters of Iran, with the description of one new species. Zootaxa 1030, 49-60.

Piersig R. 1894. - Über Hydrachniden. Zool. Anz., 17 (443/444), $107-$ 111, 113-118

Ramazzotti G. 1947. - Gli idracnidi del bacino delle Isole Borromee (Lago Maggiore). Mem. Ist. Ital. Idrobiol. Pallanza, Milano, 3 , 323-298.

Santucci J. 1970. - Contribution à l'étude du comportment estival de quelques Hydracariens (Hydrachnellae) psammiques d'un torrent de Corse - Le Porto. Ann. Fac. Sci., 44, 191-211.

Santucci J. 1971. - Contribution à l'étude de la répartition des Hydracariens (Hydrachnellae) des eaux superficielles d'un torrent de Corse - Le Porto. Ann. Fac. Sci., 45, 81-99.

Schwoerbel J. 1963. - Süßwassermilben aus Mazedonien. Acta Mus. Macedon. Sci. Nat., 9 (4), 51-75.

Stammer, H. J. 1932. - Die Fauna des Timavo. Ein Beitrag zur Kenntnis der Höhlengewässer, des Süß- und Brackwassers im Karst. Zool. Jahrb. Syst., 63 (5-6), 521-656.

Stankovic S. 1931. - Die Fauna des Ochridsees und ihre Herkunft. Arch. Hydrobiol., 23, 557-617.

Stephanides T. 1971. - Freshwater Hydracarina of the Island of Corfu, Greece. Prakt. Inst. Oceanogr. Fishing Res., Period. C, 10a, 17-21.

Taticchi M. I. 1968. - Vicende stagionali delle communità litoranee del Lago Trasimeno. Riv. Idrobiol., 7, 195-302.

Valdecasas A. \& Aviles J. G. 1983. - Some water mites (Acari, Parasitengona) from the island of Minorca. Actas del Primer Congreso Espanol de Limnologia 1981, 173-177.

Valdecasas A. \& Camacho A. I. 1986. - Las Hidracnelas leniticas de la Sierra de Guadarrama (Acari, Parasitengona, Hydrachnellae). Graellsia, 42, 149-160.

Viets K. 1930. - Zur Kenntnis der Hydracarinen-Fauna von Spanien. Arch. Hydrobiol., 21 (2), 175-240, 21 (3), 359-446.

Viets K. 1933. - Kleine Sammlungen in- und ausländischer Wassermilben. Zool. Anz., 104 (9-10), 261-274.

Viets K. 1936a. - Hydracarinen aus Jugoslavien. (Systematische, ökologische, faunistische und tiergeographische Untersuchungen über die Hydrachnellae und Halacaridae des Süßwassers). Arch. Hydrobiol., 29, 351-409.

Viets K. 1936b. - Wassermilben oder Hydracarina (Hydrachnellae und Halacaridae). Pages 31: 10+1-288., 32: 289-574 in Tierwelt Deutschlands. Dahl, F. (ed.). Jena (G. Fischer).

Viets K. 1950. - Water mites (Hydrachnellae) from Greece. Journ. Quekett Microsc. Club, London, (s. 4), 3 (3), 150-161.

Viets K. 1951. - Hydrachnellae (Acari) aus den französischen Alpen und aus Afrika. Zool. Anz., 147 (11/12), 285-303.

Viets K.O. 1961. - Neumania agilis Koenike 1916 (Hydrachnellae, Acari). Zool. Anz., 167 (5-6), 199-205

Walter C. 1925. - Hydracariens de l'Algerie et de la Tunisie (Collections de M. H. Gauthier), Première liste. Bull. Soc. Hist. natur. Afrique Nord, Alger, 16, 189-238.

Walter C. 1928. - Hydracariens de l'Algérie et de la Tunisie. (Collections de M. H. Gauthier) (Deuxième liste). Bull. Soc. Hist. natur. Afrique Nord, Alger, 19, 280-336. 